\title{
Knowledge, attitude and practice study regarding anemia in antenatal women
}

\section{Raksha M*, Shameem VPA}

\author{
Department of OBG, Bangalore Medical College and Research Institute, Bangalore, Karnataka, India
} Department of OBG, Kasturba Medical College, Mangalore, Karnataka, India

Received: 29 May 2016

Revised: 02 May 2016

Accepted: 06 June 2016

\author{
*Correspondence: \\ Dr. Raksha M, \\ E-mail: drraksha.m@gmail.com
}

Copyright: (C) the author(s), publisher and licensee Medip Academy. This is an open-access article distributed under the terms of the Creative Commons Attribution Non-Commercial License, which permits unrestricted non-commercial use, distribution, and reproduction in any medium, provided the original work is properly cited.

\begin{abstract}
Background: To study the knowledge, attitude and practices of antenatal women regarding nutrition and drug compliance in Maternal and Child Health Center, Mangalore.

Methods: The study was carried out on 200 primigravida visiting the hospital over a period of 4 months from January 2014 to April 2014. Women attending the antenatal OPD were asked to fill a questionnaire regarding anemia so as to test their knowledge, attitudes and practices pertaining to anemia and role of their diet. Inclusion criteria: Primigravida, age $>19$ years.

Results: 108 mothers out of 200 were aware of the correct sources of iron in food, however only 60 women actually implemented this in their diet practice. About 50 mothers were aware of a few maternal complications of anemia in pregnancy and 62 of them knew about fetal complications like low birth weight. The study reflects the ignorance, poverty and illiteracy among majority of the child bearing women coming to the Hospital.

Conclusions: Assessments of knowledge and practice and health education are essential step towards prevention of anaemia in pregnancy. Educating antenatal women about the importance of diet and implementing this into practice will help in the prevention of anemia.
\end{abstract}

Key words: Anemia, Primigravida, Knowledge, Attitude, Practice, Study

\section{INTRODUCTION}

Anaemia in pregnancy is one of the leading causes responsible for maternal and perinatal morbidity and mortality. WHO has estimated that prevalence of anaemia among pregnant women is $14 \%$ in developed and $51 \%$ in developing countries. $65-75 \%$ of population in India is affected with anaemia. ${ }^{1}$ In India; anaemia is directly or indirectly responsible for 40 per cent of maternal deaths. There is 8 to 10 fold increase in MMR when the $\mathrm{Hb}$ falls below $5 \mathrm{~g} / \mathrm{dl}$. Early detection and effective management of anaemia in pregnancy can contribute substantially to reduction in maternal mortality. ${ }^{2}$ Maternal anaemia is associated with poor intrauterine growth and increased risk of preterm births and low birth weight rates. ${ }^{3,4}$
The present study was descriptive in nature. The objectives of the study was to assess the knowledge and practice regarding prevention of anaemia among antenatal women.

\section{METHODS}

The study was carried out on 200 primigravida attending the antenatal OPD in a Maternal and Child health center in Mangalore over a period of 4 months. Hospital ethical committee permission was obtained. After taking informed consent 200 antenatal women were selected by systematic random sampling method. Knowledge and practice was assessed using structured interview schedule 
which included questionnaire on knowledge and selfreported rating scale to assess the practice regarding prevention of anaemia. Descriptive and inferential statistics was used to analyze the data. All the primigravida attending the antenatal OPD will be asked to fill a questionnaire regarding anemia so as to test their knowledge, attitudes and practices pertaining to (a) Dietary sorces of iron (b) Consumption of iron rich food (c) Consequences of low hemoglobin count in mother (maternal complications of anemia ) (d) Effects of anemia on fetus and pregnancy outcome (e) Assessing their drug compliance (f) Importance of high protein diet in the correction of anemia (g) Sources of knowledge.

\section{Inclusion criteria}

Primigravida, age $>19$ years.

\section{RESULTS}

The following data was obtained from the present study.

Majority of the women, 111 out of 200 belonged to 19 to 25years age group. 69 women belonged to the 25 to 30 years age group and 20 women belonged to $>30$ years age group (Figure 1).

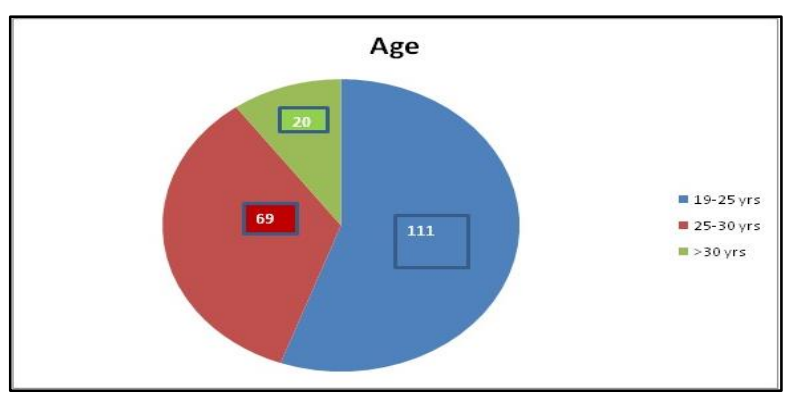

Figure 1: The age of the antenatal woman included in the study.

Out of the 200 women included in the study 102 belonged to lower socio economic status, 62 belonged to the upper lower class, 30 belonged to the lower middle class and 6 to upper middle class (Table 1).

Table 1: The socio economic status of all the antenatal women.

\begin{tabular}{|ll|}
\hline Socio economic status & $\begin{array}{l}\text { Number of antenatal } \\
\text { Women }\end{array}$ \\
\hline Lower socio economic status & 102 \\
\hline Upper lower & 62 \\
\hline Lower middle & 30 \\
\hline Upper middle & 6 \\
\hline Upper & - \\
\hline
\end{tabular}

About 63 patients registered in the first trimester, 102 patients registered in the second trimester and 35 patients registered in the third trimester (Table 2).
Table 2: The number of antenatal women and the trimester in which they first reported to the hospital.

\begin{tabular}{|ll|}
\hline Trimester of pregnancy & $\begin{array}{l}\text { Number of antenatal } \\
\text { women }\end{array}$ \\
\hline $1^{\text {st }}$ trimester & 63 \\
\hline $2^{\text {nd }}$ trimester & 102 \\
\hline $3^{\text {rd }}$ trimester & 35 \\
\hline
\end{tabular}

$64 \%$ of the women were aware of the food items which were a rich source of iron, however only $30 \%$ of them implemented these food items in their daily diet. $50 \%$ were aware of high protein diet in the correction of anaemia (role in heme binding). None of the women were aware of any of the inhibitors of iron absorption.

Only $25 \%$ of the women were aware of a few maternal complications of anemia like PPH, cardiac failure, failing lactation, recurrent infections and only $31 \%$ of them were aware of fetal complications like IUGR, infections leading to preterm labour. Role of deworming was known to 22 women out of the 200 . Only 5 women were not compliant to the iron medication.

Almost $60 \%$ of the women said that all the knowledge they had, was imparted to them by medical or para medical professionals, $22 \%$ attributed it to their family and friends while the remaining $18 \%$ acquired it via books and television (Figure 2).

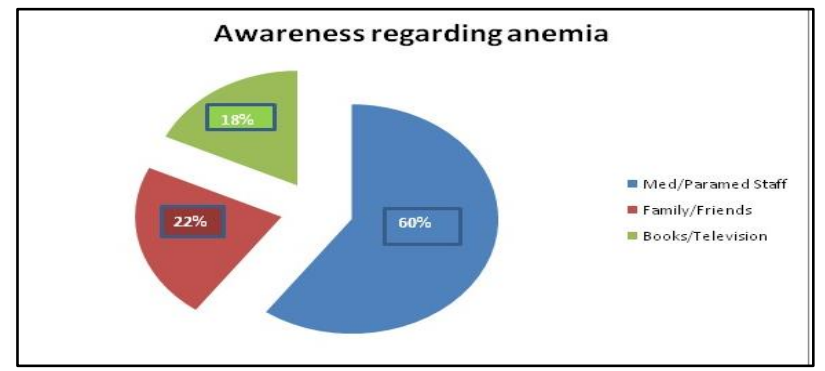

Table 2: The various means through which the mothers obtained their knowledge regarding anemia.

\section{DISCUSSION}

Anemia is a major public health problem throughout the world, particularly for women of reproductive age in developing countries. In India anemia is a common cause of maternal morbidity and mortality and a key factor related to low birth weight. ${ }^{3,5}$ A significant association of anemia with socioeconomic status and educational status suggests a need to develop strategies for intensive adult education and to improve the socio economic status of the population through poverty-alleviation programs. ${ }^{6}$

The present study highlighted the importance of providing information to all the antenatal women in the clinics regarding beneficial and non-beneficial practices to prevent anaemia in pregnancy. Even though drug 
compliance was good, faulty drug intake habits such as taking iron and calcium tablets together or with milk decreased the absorption and ultimately the desired outcome of the treatment. It also shows that drug compliance for iron and folic acid (free supply) has significantly improved not only because of the cost factor but also due to the reinforcement of their knowledge by the staff. ${ }^{7}$ Mistrusts among pregnant women towards hematinics can be corrected with adequate education. ${ }^{8}$ The study also reflects the ignorance and lack of education among majority of child-bearing women especially of low socioeconomic class.

Very few antenatal women have done de-worming before or during pregnancy. There should be mandatory preconception and antenatal counselling sessions of structured teachings to the antenatal women to identify the risk factors in pregnancy and to reduce the enormous burden of anemia in pregnancy. The current emphasis on health for all demands that every individual should be self-sufficient and self-reliant. ${ }^{9}$

\section{CONCLUSION}

Our study supports the conclusion that educating antenatal women about the importance of diet and implementing this into practice will help in the prevention of anemia. There should be mandatory preconception and antenatal counselling sessions for the women to identify the risk factors in pregnancy and structured teachings to reduce the enormous burden of anemia in pregnancy. Continuous reinforcement of knowledge to women by health workers may bring about a change in their nutritional habits, adopting contraceptive methods, and ensuring early registration and regular follow up which will go a long way to help in reducing the incidence of anemia. ${ }^{4,10}$ It is also proposed that such repeated attempts of counselling for dietary measures of anemia can help in the prevention and correction of anemia which is the commonest morbid condition prevailing in our country and also the leading cause of maternal mortality.

Funding: No funding sources Conflict of interest: None declared
Ethical approval: The study was approved by the Institutional Ethics Committee

\section{REFERENCES}

1. Sivapriya SM, Parida L. A study to assess the knowledge and practices regarding prevention of anemia among antenatal women attending a tertiary level hospital in Pune. IJSR NET. 2015;4(3):121014.

2. Khan KS, Wojdyla D, Say L, Gülmezoglu AM, Van Look PF. WHO analysis of causes of maternal death: a systematic review. Lancet. 2006;367:1066-74.

3. Alam AY, Qureshi AA, Adil MM, Ali H. Comparative study of knowledge, attitude and practices among antenatal care facilities utilizing and non-utilizing women. J Pak Med ASSoc. 2005;55(2):53-6.

4. Kulkarni KK. KAP study among Indian antenatal women: can we reduce the incidence of anemia? The J Obstetr Gynecol India. 2015;65(5):320-2.

5. Benoist DB, Mclean E, Egli I, Cogswell M. Worldwide prevalence of anemia 1993-2005: WHO Global Database on Anemia 2008.

6. Rizvi F. Impact of maternal education, and socioeconomic status on maternal nutritional knowledge and practices regarding iron rich foods and iron supplements. Ann Pak Inst Med Sci. 2012;8(2):101-5.

7. Kalaivani K. Prevalence and consequences of anemia in pregnancy. Indian J Med Res. 2009;130(5):62733.

8. Sanghvi TG, Harvey PW, Wainwright E. Maternal iron-folic acid supplementation program: evidence of impact and implementation. Food Nutr Bull. 2010;31(2):100-7.

9. Noronha JA, Khasawneh EA, Seshan V, Ramasubramaniam S, Raman S. Anemia in pregnancy- consequences and challenges: A review of literature. J SAFOG. 2012;4(1):64-70.

10. Yajnik C, Coyaji K, Joglikar C, Kinare A, Rao S. Pune maternal and nutrition study. Fife Epidemiology Unit 2010.

Cite this article as: Raksha M, Shameem VPA. Knowledge, attitude and practice study regarding anemia in antenatal women. Int J Reprod Contracept Obstet Gynecol 2016;5:2101-3. 